\title{
APREENSÃO DA TRANSFORMAÇÃO DO TERRITÓRIO COSTEIRO DE LAGUNA - BRASIL. Estudo comparativo dos processos de crescimento dos balneários Farol de Santa Marta e Itapirubá.
}

\author{
Eduardo Nogueira Giovanni; Vinicius Simão Rzatki; Emiliane Becker de Souza \\ UFSC/CTC/PósARQ - UDESC/DAU \\ Orientador da tese: Almir Francisco Reis \\ dugiovanni@hotmail.com
}

\section{RESUMO}

Esta apresentação trata-se de parte de uma pesquisa em andamento junto à UFSC e UDESC que visa compreender os processos de crescimento das estruturas urbano turísticas em Laguna-SC. O objeto deste estudo são os assentamentos Farol de Santa Marta e Itapirubá, nos extremos opostos do município estudado que, a princípio, apresentavam muitas similaridades entre si. O objetivo é elaborar uma leitura urbano-ambiental do território estudado e também testar o método de análise para compreensão do sítio e da realidade destes lugares. Como aporte teórico principal, tem-se o trabalho de Sola Morales y Rubió (1993) que aborda as formas de crescimento urbano. Sua realização foi feita através de leituras e interpretações de três levantamentos aerofotogramétricos e uma imagem de satélite, de diferentes períodos. Os resultados das análises gráficas permitiram a confirmação das similaridades nas origens dos assentamentos e mostraram, que, ao longo dos anos, foram surgindo distinções bastante significativas na configuração destes casos.

Palavras chaves: ocupação urbana/ processo de crescimento/ turismo/ Laguna

\begin{abstract}
This presentation is part of an ongoing research between UFSC and UDESC, aiming to understand the processes of growth of urban tourism structures in Laguna-SC. The object of this study is the settlements of Farol de Santa Marta and Itapirubá, at opposite ends of the studied city, which, at first, presented many similarities among themselves. The objective is to elaborate an urban-environmental reading of the studied territory and also to test the method of analysis to understand the site and the reality of these places. As the main theoretical contribution, we have the work of Sola Morales and Rubió (1993) that addresses the forms of urban growth. Its development were made through readings and interpretations of three aerophotogrammetric surveys and satellite images of time spans. The results of the graphical analyzes allowed the confirmation of the similarities in the origins of the settlements and showed that, over the years, there were quite significant distinctions in the configuration of these cases.
\end{abstract}

Key words: urban occupation / growth process / tourism / Laguna 


\section{APRESENTAÇÃO}

Entre o complexo lagunar e a costa marítima, situados ao sul do Estado de Santa Catarina, localizase, em uma estreita faixa de terra, o município de Laguna. Este município vem sofrendo alterações devido às atividades turísticas e estas se intensificaram a partir da década de 70 e provocando significativas alterações em suas paisagens naturais e urbanas. Esta apresentação visa apresentar e debater como esse processo de transformação urbano-turística incide sobre dois assentamentos originalmente pesqueiros localizados nos extremos do município. Entende-se que a compreensão dos processos de transformações urbanas é crucial para o debate e proposição das cidades.

O objetivo deste trabalho é a realização de uma leitura urbano-ambiental das infraestruturas urbanoturísticas de Itapirubá e Farol de Santa Marta, em Laguna - SC, a partir de duas dimensões de análise: processos de crescimento urbano e sítio físico. Essas leituras foram realizadas através de análises gráficas sobre imagens do território de diferentes períodos. Também é objetivo deste estudo testar e apropriar-se do método proposto para a compreensão do território e também de sua realidade.

Este trabalho é parte de uma pesquisa em elaboração junto à Universidade do Estado de Santa Catarina - UDESC cujo objetivo é investigar os processos de crescimento das estruturas urbanoturísticas encontradas no município de Laguna, localizado ao sul do Estado de Santa Catarina Brasil. Articula-se também com uma pesquisa de doutorado, em andamento junto à Universidade Federal de Santa Catarina, que visa relacionar a compreensão destes processos de crescimento com a forma urbana e os impactos junto ao sítio físico original no município de Laguna-SC.

\section{INTRODUÇÃO}

O crescimento da atividade turística no Estado de Santa Catarina tem desdobramento direto na transformação das paisagens costeiras e de seus assentamentos preexistentes, de forma que os valores cênicos destes locais, como restingas, dunas e lagoas não são consideradas nas ocupações mais recentes. O resultado é a formação de malhas urbanas descontextualizadas e mal inseridas, descaracterizando de forma irreversível as qualidades de seu sítio original.

Essa questão também é notória no território do município de Laguna, uma das três primeiras cidades do Estado de Santa Catarina, situada na costa sul brasileira (figura 1), entre o oceano Atlântico, à leste, e o Complexo Lagunar Santo Antônio dos Anjos, à oeste. Apresenta uma área de $336.396 \mathrm{~km}^{2}$ (IBGE, 2017), disposta numa faixa de terra com feições peninsulares devido a sua localização entre os dois corpos d'água.

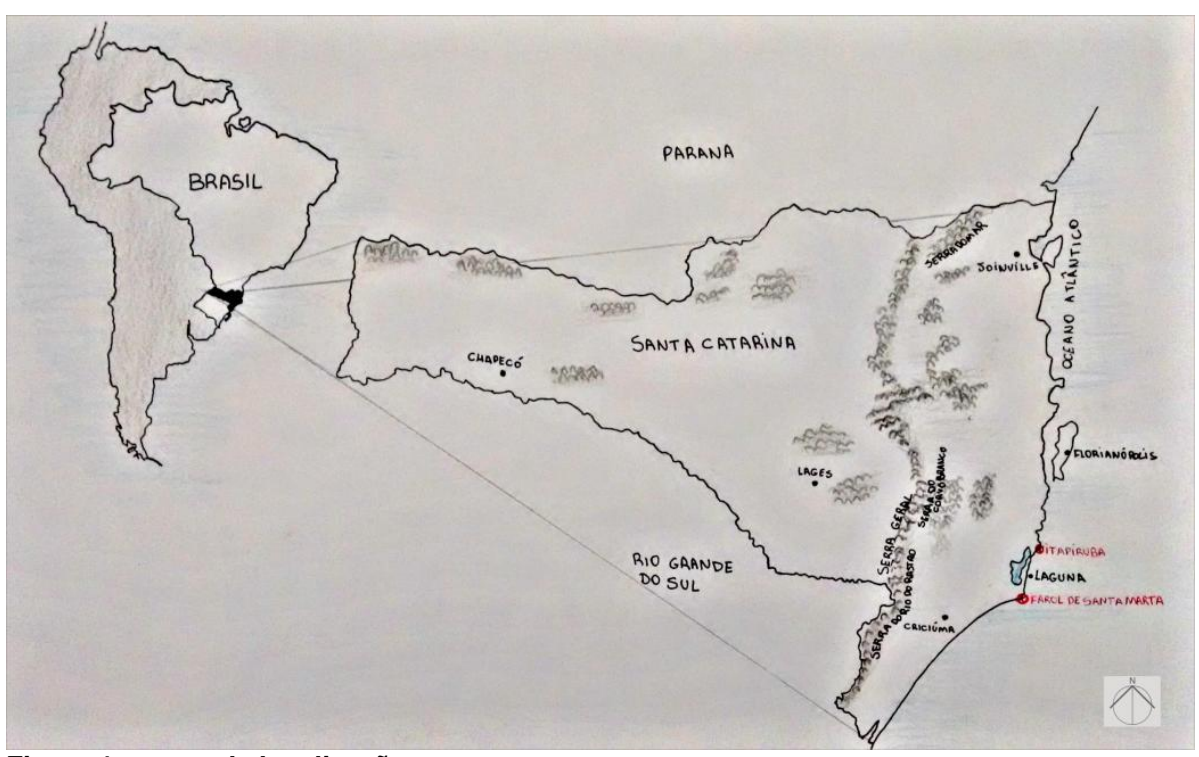

Figura 1 - mapa de localização

Elaboração própria a partir de dados do Google - Desenho, Emiliane Becker de Souza 
Neste trecho do litoral observa-se a presença de costões e promontórios rochosos que se alternam com as terras baixas, sedimentares, que compõem a planície costeira que conta com a presença de lagunas costeiras, barreiras arenosas, dunas, praias e desembocaduras fluviais (Gré, 2013), como a advinda do rio Tubarão que deságua no complexo lagunar de Santo Antônio dos Anjos. (figura 2)

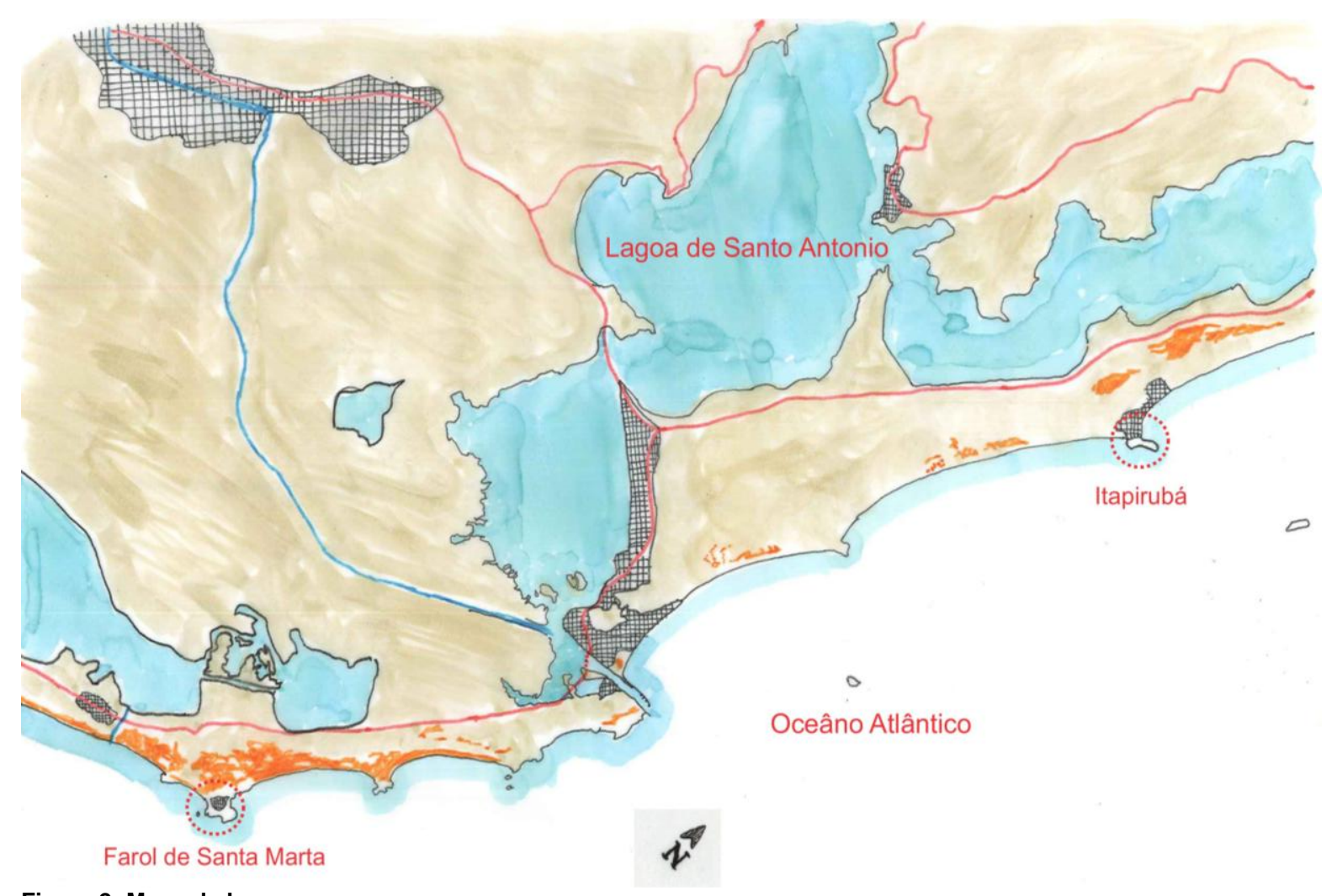

Figura 2- Mapa de Laguna

Elaboração própria a partir de dados do Google - Desenho, Vinícius S. Rzatki.

Esta diversidade física e geológica contribui para a singularidade da paisagem em que o município está inserido, onde a paisagem natural predomina sobre a reduzida ocupação urbana. Também foram estas condições e as diferentes qualidades de suas paisagens que fizeram com que a cidade de Laguna se distribua em diferentes assentamentos fragmentados entre si e pouco articulados com seu centro histórico original.

É possível observar, que a cidade de Laguna, descontinuada ao longo de seu território, tem seus assentamentos costeiros pouco conectados, o que torna-os relativamente independentes entre si, uma vez que, em alguns deles, só é possível acessar através de rodovias federais ou estaduais. Observa-se também que, de forma destoada, a cidade vem modificando trechos de sua malha urbana ao ponto em que a especulação imobiliária dita o ritmo do desenvolvimento de pequenos e grandes empreendimentos, sendo eles baseados no anseio da população regional optar por terem suas "segundas residências" à beira de corpos d'água em busca do ócio junto ao sol e ao mar.

Trabalha-se com o pressuposto de que os assentamentos urbano-turísticos desta cidade apresentam semelhanças em suas características espaciais e em seu processo de desenvolvimento. Além de apresentarem origem similar enquanto processo de crescimento, foram construídos sobre um sítio físico que apresenta características geomorfológicas aproximadas e acredita-se que os impactos sobre o meio natural também sejam equivalentes.

Entende-se também que, apesar de vários aspectos em comum, apresentam também peculiaridades que são importantes de serem compreendidas, verificadas e valorizadas. A identificação de como estas características singulares refletem nas formas urbanas e nas qualidades de espaços públicos 
podem ser elementos geradores de identidade agregando qualidades nas formas resultantes dos processos de urbanização. De acordo com Saraiva, (2005:354), “.... Aos lugares litorâneos escolhidos para serem cidades, não basta o planejador dizer não, opondo-se ideologicamente, a elas mas sim, com que desenho alternativo e com que qualidades podem e devem continuar a ser feitas."

Neste sentido, o objetivo deste trabalho é a realização de uma leitura urbano-ambiental das infraestruturas urbano-turísticas de Itapirubá e Farol de Santa Marta, em Laguna - SC analisando, identificando e registrando graficamente as semelhanças e distinções destes dois assentamentos situados nos extremos opostos do território estudado. É também objetivo deste estudo testar e apropriar-se do método proposto para a leitura do território e também da realidade deste território estudado.

A realização desta leitura é feita sobre três levantamentos aerofotogramétricos e uma imagem de satélite realizados em diferentes períodos: 1938, 1957, 1977 e 2016, (quadro 1), abordando dois aspectos norteadores da pesquisa: processos de crescimento urbano e sítio físico/meio ambiente.

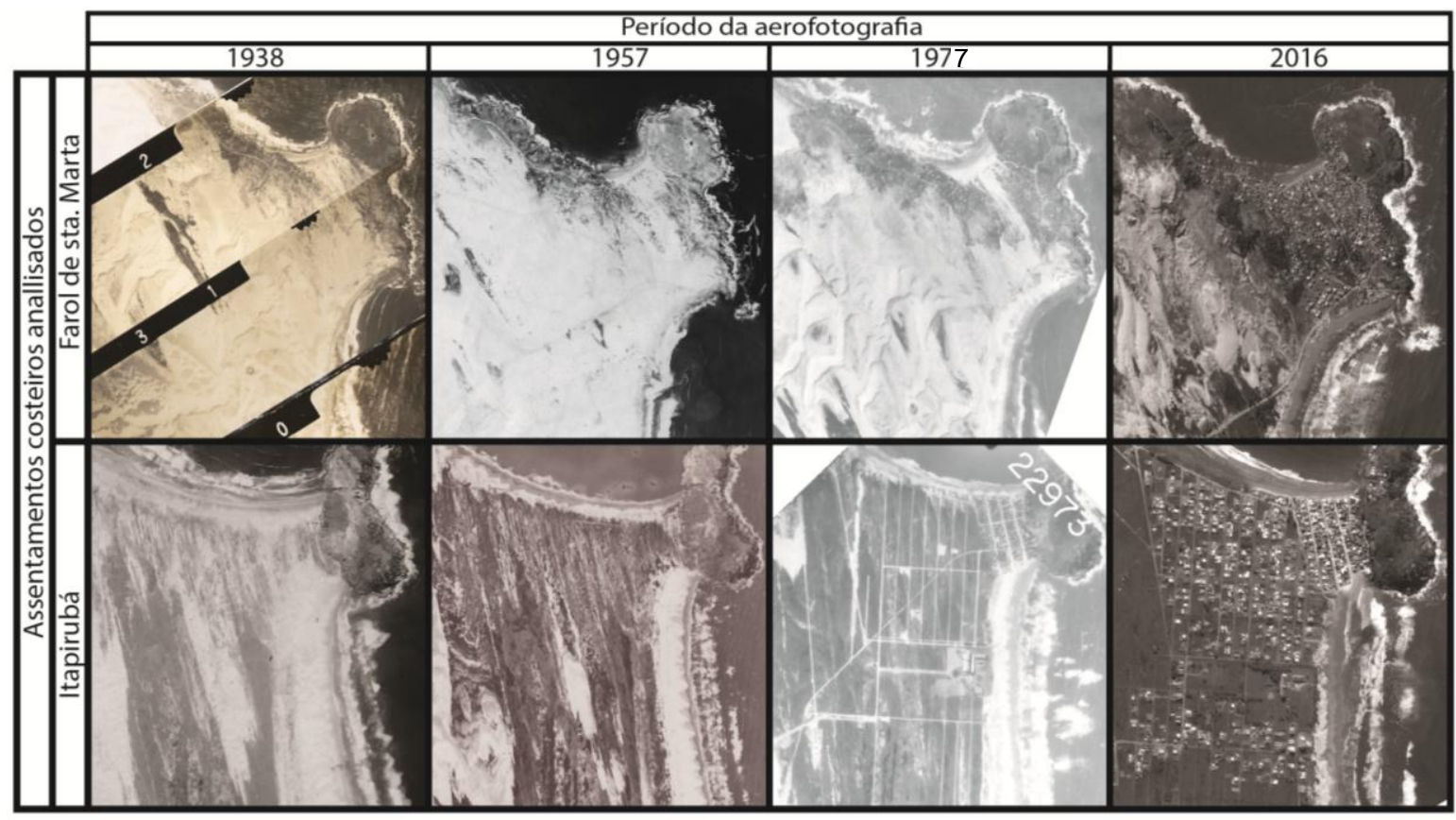

Quadro 1 - Farol de Sta. Marta e Itapirubá nos períodos de 1938, 1957, 1977 e 2016

Elaboração própria a partir de dados de Santa Catarina, 2017 e do Google, 2017.

Entre os principais suportes teóricos utilizados para o desenvolvimento deste trabalho, foi escolhido, para o entendimento das formas de crescimento urbano dos assentamentos turísticos estudados, o trabalho desenvolvido por Solà Morales y Rubió (1993), que tipifica as formas de crescimento urbano de acordo com o encadeamento das operações urbanas (parcelamento, infraestrutura e edificação) nos processos de ocupação, relacionando-os com o tempo e o espaço.

A partir desta referência, é possível identificar, no município de Laguna, similaridades nos processos de crescimento dos distintos assentamentos urbano-turísticos existentes, sendo aceitável tipificá-los. Desta forma, foram definidos os dois recortes para o presente estudo, pois acredita-se que os mesmos se assemelham, a princípio, em relação ao processo de crescimento urbano e à paisagem natural. Situados nos limites opostos norte e sul do município, seus processos de crescimento são investigados com maior profundidade para o entendimento da evolução destes assentamentos enquanto resultantes de um processo temporal.

No que tange classificar e tipificar a paisagem urbana e natural, o Projeto Orla, Projeto de Gestão Nacional da Orla Marítima brasileira, criado em 2002, busca implementar, "uma política nacional que harmonize e articule as práticas patrimoniais e ambientais com o planejamento de uso e ocupação desse espaço que constitui a sustentação natural e econômica da zona costeira". Sendo assim, quanto ao entendimento do sítio físico, estas publicações dão o apoio para a compreensão das 
unidades de paisagem identificadas nos assentamentos analisados, levando em consideração aspectos como a mancha urbana, cobertura natural e conflitos socioeconômicos.

Logo, o recorte de área urbana composto de orla dentro das cidades costeiras é analisado em relação a dimensão e tipo do traçado, formas de acesso à praia, estágio de urbanização, verticalidade dos edifícios e configuração paisagística da mancha urbana. Não menos importante, o projeto orla também classifica a paisagem natural, que descreve a mesma através da presença de seus promontórios, das praias e das matrizes vegetais presentes.

O trabalho de Scherer et al (2016) complementa o entendimento das unidades de paisagens a partir de sua classificação de sistemas ambientais. Esta leitura ao longo dos diferentes períodos está registrada graficamente e com elas é possível observar como estes sistemas ambientais vêm sendo alterados em função da evolução destes novos assentamentos.

Como resultados, observou-se que os dois assentamentos estudados, mostraram mais diferenças do que similaridades ao longo dos processos de ocupação. Notou-se também uma ocupação aparentemente mais agressiva aos sistemas ambientais em Itapirubá do que no Farol de Santa Marta e, finalmente, que a partir da década de 1970, as diferenças nos tipos de ocupação ficam ainda mais evidenciadas.

\section{TURISMO, DESENVOLVIMENTO URBANO E CARACTERIZAÇÃO DA ATIVIDADE TURÍSTICA EM LAGUNA - SC}

Em todo o mundo a faixa litorânea caracteriza-se por apresentar índices elevados de densidade demográfica e esta tendência é reforçada em países de formação colonial, como o Brasil. O seu litoral conta com mais de 8 mil quilômetros de extensão e apresenta dezenas de estuários, uma série de praias, promontórios e planícies costeiras, que por sua forma e extensão tornam-se convidativas à ocupação, apesar de nem todas serem passíveis de urbanização em função de aspectos geomorfológicos. Por isso, grande parte dela tem sido constantemente modificada pelo homem (Brasil, 2004).

Apesar do processo de colonização brasileira ter se originado a partir da costa litorânea, ainda no começo do século XX praias, lagoas ou lagunas não eram reconhecidas como uma figura urbana e projetos como a orla de Copacabana foram os primeiros registros de urbanização levando em consideração os valores paisagísticos litorâneos (Brasil, 2004).

Este início do processo de valorização da paisagem costeira no Brasil ocorre simultaneamente às conquistas sociais e econômicas da metade do Séc. XX. As camadas de média e alta renda investiram em pequenos e grandes loteamentos guarnecidos de orla marítima. Estes popularizaramse pela representação de status e, ao contrário de Copacabana, que se inseriu no contexto urbano da capital carioca, apresentam predominantemente o lazer sazonal permanecendo como uma infraestrutura ociosa nos períodos de baixa temporada.

Provenientes da massificação da atividade turística, pequenas cidades litorâneas tornaram-se espaço para o acúmulo de capital através da especulação imobiliária, aumentando as atividades de construção civil em suas orlas. Isto ocasiona um crescimento intermitente e irregular, dando origem a tecidos urbanos descontextualizados com seus meios onde valores paisagísticos e ambientais não são objetos de atenção imediata nem para o empreendedor, nem para a maioria do público consumidor, sendo eliminados quando necessário (Brasil, 2004).

No Estado catarinense, segundo Saraiva (2005: 241), “... a construção e término da BR - 101, em 1970 ... articulando as principais cidades, todas situadas próximas a franja litorânea, ao centro do país. Assim sendo, aquelas regiões que, paradoxalmente, eram tratadas como fundos distantes, passam desde aí, desempenhar seu verdadeiro papel de principal na fachada atlântica do sul brasileiro". O desenvolvimento deste trecho do litoral se intensifica e, a rodovia federal, além de ligar - País de norte a sul, articula os bairros mais afastados de Laguna com seu centro urbano e com as cidades vizinhas. Este fato acelerou o ritmo das transformações da paisagem em decorrência da 
especulação imobiliária, que investe nesta região onde a aquisição de residências de veraneio em diferentes assentamentos deste município é procurada por moradores da própria e de outras cidades. Santa Catarina possui 295 municípios, distribuídos em 95,4 mil km² e sua capital Florianópolis. Com aproximadamente $560 \mathrm{~km}$ de extensão (SANTUR, 2017), sua costa apresenta uma diversidade de praias com características bastantes distintas umas das outras. Isto faz com que o litoral catarinense seja um dos destinos turísticos mais concorridos do Brasil, principalmente durante os meses da temporada do verão, onde, anualmente, cerca de 5 milhões de visitantes, incluindo estrangeiros (vindos em sua maioria da própria América do Sul), brasileiros de outros estados e os próprios catarinenses que buscam conhecer e vivenciar as belas praias deste Estado.

Situada no litoral centro-sul do Estado (figura 3), Laguna tem uma população de 40.290 habitantes, sendo eles 40.096 em áreas urbanas e 194 em áreas rurais. (IBGE, 2010). Seu território está disposto numa área de $353 \mathrm{~km}^{2}$ e localiza-se a $118 \mathrm{~km}$ ao Sul da capital Florianópolis. O município insere-se na Mesorregião Sul Catarinense, especificamente entre os 19 municípios que compõem a Microrregião de Tubarão e representa-se, enquanto associação dos municípios que fazem parte da FECAM (Federação Catarinense dos Municípios), pela AMUREL (Associação dos Municípios da Região de Laguna).

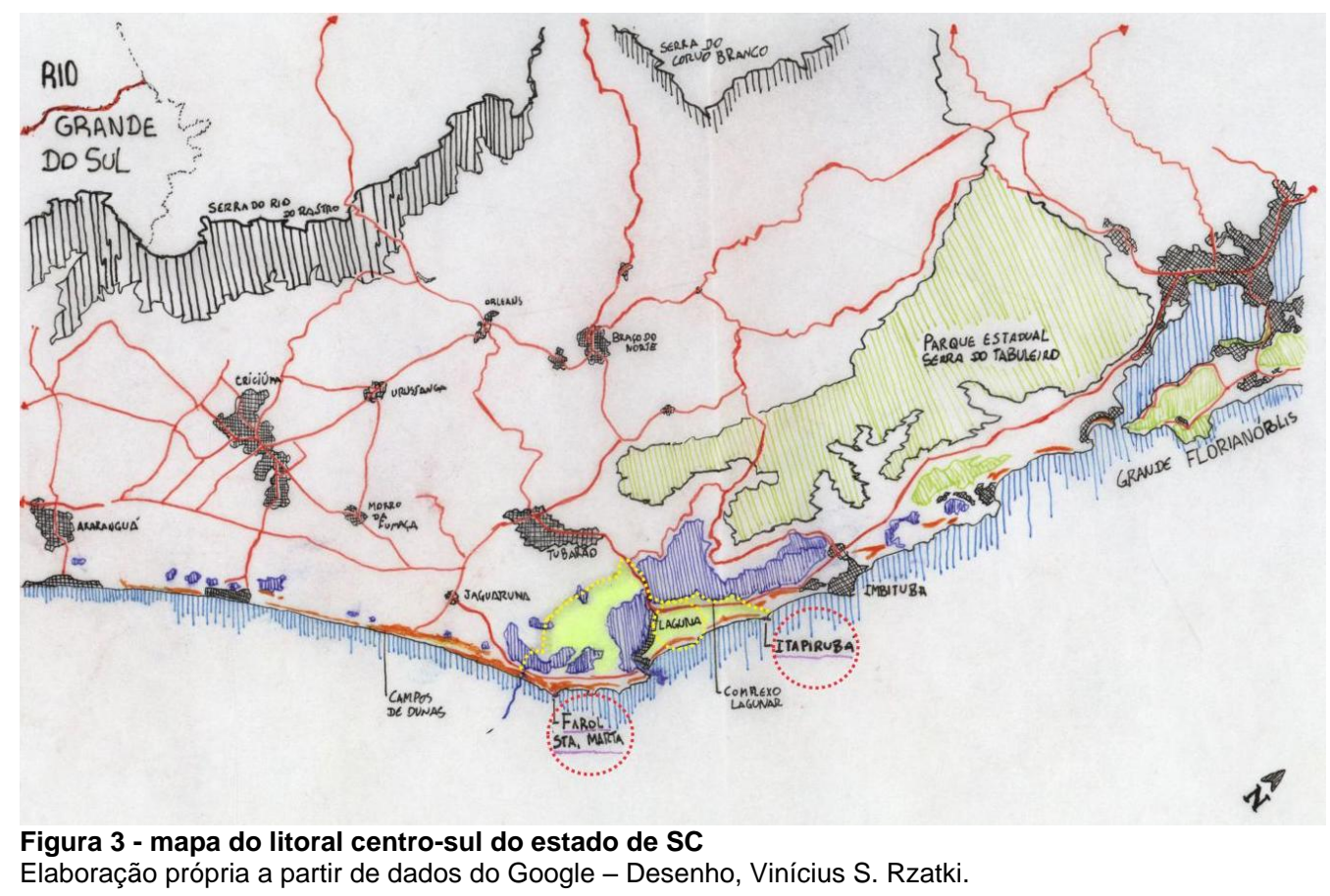

A fim de preservar o rico patrimônio natural e cultural, o Estado conta com 24 unidades de preservação. Destas, destaca-se a Área de Proteção Ambiental Baleia Franca (APA Baleia Franca), que foi criada pelo decreto federal $\mathrm{s} / \mathrm{n}^{\circ}$ em 14 de setembro de 2000 . Abrange $130 \mathrm{~km}$ de costa marítima e totalizando uma área de 156 mil hectares, que começa no sul da ilha de Santa Catarina, passa pelo território de Laguna e se estende até o Balneário Rincão. (ICMBIO)(Figura 4) 


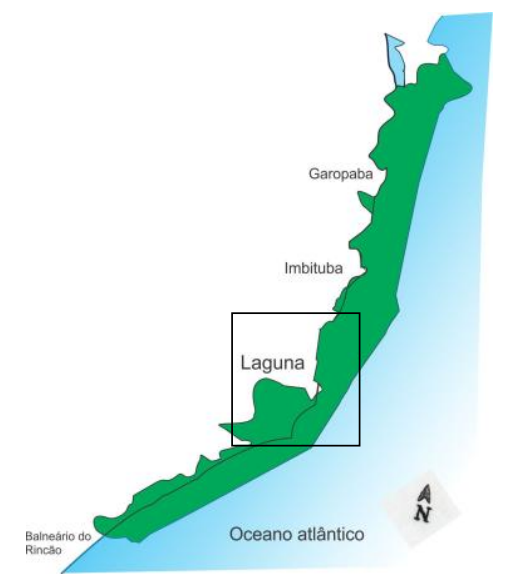

Figura 4 - Mapa da APA Baleia Franca

Elaboração própria a partir de dados do ICMBIO

Esta unidade de conservação da tem como função proteger as águas marinhas bem como a paisagem preexistente em lugares como ilhas, promontórios, praias, restingas, dunas e sambaquis, disciplinando e monitorando o uso e a ocupação do solo decorrente de fatores bióticos e abióticos, o turismo e as malhas urbanas crescentes.

A partir do mapa interativo disponibilizado pela ICMBIO (2016), consegue-se apontar com mais precisão o mosaico da área no qual a APA atua. A costa de Laguna inserida na APA (Figura 5), não incluem todas as áreas da faixa de terra da praia de Itapirubá, do Iró e do Mar Grosso.

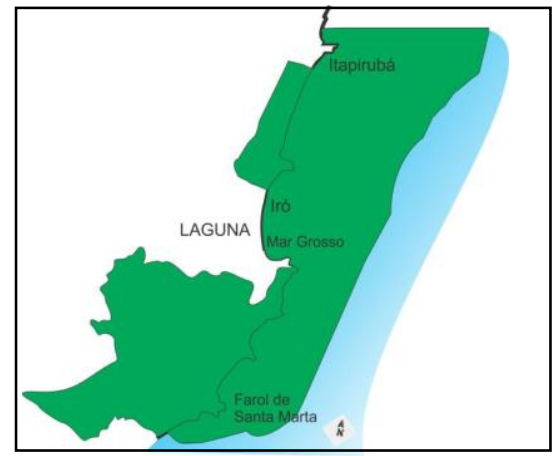

Figura 5 - Mapa da APA Baleia Franca em Laguna

Elaboração própria a partir de dados do ICMBIO

\subsection{Laguna - História e transformação do território}

Acredita-se ser pertinente ressaltar a presença de forte contexto histórico que incide sobre a cidade de Laguna, que já teve uma importância significativa no contexto nacional e foi um ponto de ponto de referência da região sul, à época do Brasil colônia e assim se manteve durante muitos anos da história deste País. Considerada como local estratégico para defesa do território colonial, Laguna era a porção de terra mais ao sul onde o meridiano de Tordesilhas dividia Brasil colônia da América Espanhola. Foi o último ancoradouro seguro para as tropas militares, onde eram abastecidas de mantimentos e que se locomoviam ao extremo sul, em direção à Colônia de Sacramento, visando defender os interesses da coroa portuguesa para manter o acesso junto ao Rio da Prata

No Séc. XVIII, o porto se se localizava onde, hoje, é o centro da cidade, um local abrigado pelo morro da Glória e com acesso ao estuário da lagoa de Santo Antônio dos Anjos. Seu porto foi peça fundamental para escoar produtos da colônia e principalmente o gado proveniente dos caminhos tropeiros, que desciam de Lages em direção a Laguna, onde eram abatidos e transportados para o sudeste brasileiro. Tal estrutura também era a principal porta de entrada de imigrantes fomentando a urbanização e o crescimento da região na época.

A Ferrovia D. Thereza Christina foi construída ao longo de quatro anos no final séc. XIX, a partir da chancela do Barão de Barbacena, que atraiu financiamento britânico para o sul do Estado 
catarinense. Esta estrada de ferro foi importante para o desenvolvimento de boa parte desta região e também pela transformação de suas paisagens, que, com o crescente mercado de carvão da época, transportava o minério que saia da região mais ao sul em direção à Laguna e, seus vagões, retornavam com imigrantes europeus que colonizaram as pequenas vilas de onde o minério era extraído.

Devido à presença do porto e da ferrovia - portas de conexão com o comércio global, Laguna viveu seu auge econômico, fato grifado em sua rica arquitetura na parte central da cidade, artefato histórico patrimonial nacional protegido por lei, em forma de conjunto, há cerca de trinta anos.

Atualmente, sem o ramal que adentrava ao município (o mesmo foi suprimido da ferrovia ainda existente), e a mudança de caráter de seu porto (que outrora foi de suma importância para a colonização da região sul do estado passando a atuar, nos dias de hoje, exclusivamente em função da atividade pesqueira), a economia da cidade passa a se fundamentar em atividades ligadas à pesca e ao turismo. Esta última vem se consolidando a partir da presença das infraestruturas turísticas construídas a partir da metade do Séc.XX, fato confirmado a partir dos indicativos espaciais verificados ao longo dos anos através das análises das imagens trabalhadas para este estudo.

\section{O RECORTE DE ESTUDO: ITAPIRUBÁ E FAROL DE SANTA MARTA}

O trabalho de Solá Morales (1993) permite a construção de tipologias urbanas a partir da análise de seus processos de crescimento. Verificou-se que determinados assentamentos pertencentes ao município de Laguna apresentam semelhanças em suas origens e podem ser considerados elementos de uma mesma categoria tipológica.

Os assentamentos analisados neste trabalho têm como origem a evolução de assentamentos pesqueiros, os quais comportavam-se, originalmente, como ilhas desconectadas no vasto território do município de Laguna. Foram selecionados para análise os assentamentos conhecidos como Farol de Santa Marta, ao extremo sul do município e Itapirubá, localizado no extremo norte de Laguna. (Figura 6).
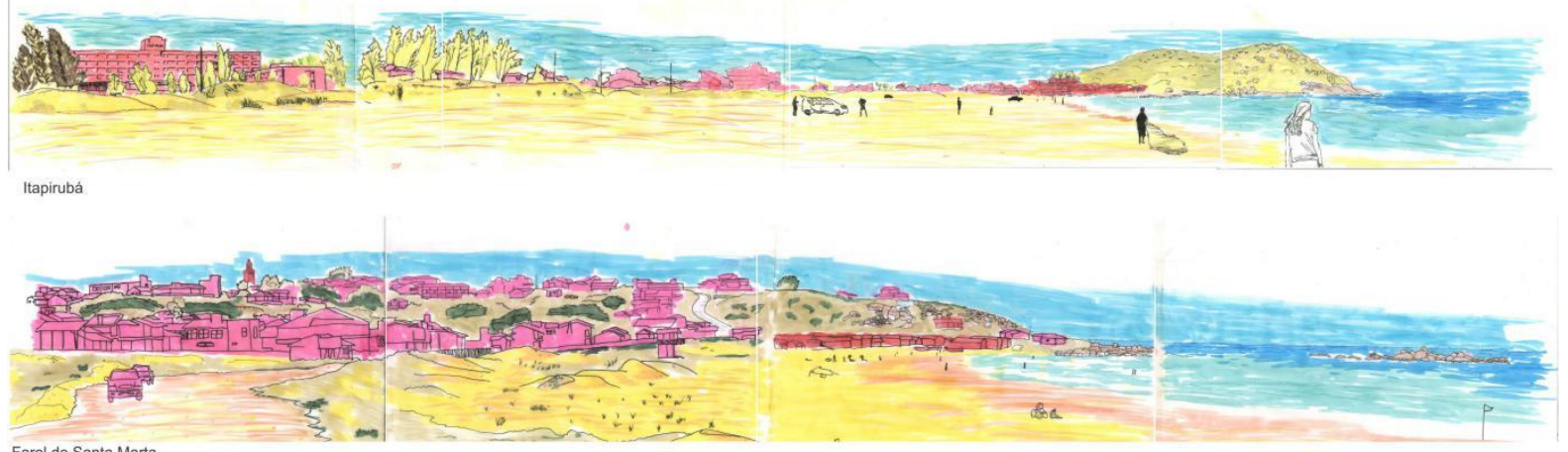

Firol de Santa Marta 6 - Skyline de Itapirubá e do Farol de Santa Mart

Elaboração própria - Desenho, Vinícius S. Rzatki.

Os assentamentos escolhidos no município de Laguna para estudo têm processos de crescimento semelhantes entre si e são relativamente autônomos levando em consideração a presença de serviços e comércio em cada um deles. Ambos apresentam também semelhanças em sua escala e também em sua inserção junto ao sítio físico.

A comunidade do Farol de Santa Marta, situado ao limite sul do município, tem uma infraestrutura viária de acesso precária que se conecta à SC-100, rodovia estadual que cruza diversas comunidades ao sul do território municipal e estadual encerrando-se, ao norte, na margem sul do canal que conecta a Lagoa de Santo Antônio dos Anjos ao oceano Atlântico. A transposição deste canal ocorre por um sistema de balsas e botes que conectam à margem norte, a partir de onde temse, então, acesso ao centro da cidade. 
Esta comunidade, situa-se em um ponto de inflexão geográfica que demarca o fim dos trechos sinuosos de orla no litoral de Santa Catarina. Trata-se de um promontório rochoso, denominado Cabo de Santa Marta e que serviu como abrigo de intempéries permitindo a fixação da comunidade que originou a ocupação local. Nesta feição rochosa foi implantado, no final do século XIX, um farol para guiar as embarcações para longe do Parcel do Campo Bom. Tornou-se então, desde sua implantação uma forte referência na paisagem sul catarinense. A orla ao entorno deste promontório é constituída de duas praias: a Prainha, que conta com sua orla abrigada e a praia do Cardoso, cuja orla é semi abrigada em relação à incidência direta das ondulações.

Itapirubá, por sua vez, é uma comunidade situada no extremo norte do município de Laguna, no limite territorial com o município de Imbituba e espalha-se, nesta porção de terra, pelos dois municípios. Assim como no caso do Farol de Santa Marta, Itapirubá não tem uma conexão direta com o centro de Laguna, porém, suas vias de acesso são mais facilitadas, uma vez que não é preciso fazer nenhuma travessia por balsas ou botes, porém, só é possível acessar a comunidade passando junto ao leito da BR-101.

Também se originou nas bases de um promontório que oferecia proteção das intempéries à comunidade que ali começava a se instalar, permitindo que ali se fixasse. Sua orla é composta, além de seu promontório por duas praias: Itapirubá Sul e Itapirubá Norte, sendo que a praia ao sul do costão rochoso pertence ao município de Laguna e a praia ao norte deste costão faz parte do município vizinho. No assentamento não é possível perceber o limite físico entre estas duas cidades.

\subsection{Farol de Santa Marta}

Observando as imagens de 1938 e 1957, notou-se que houve pouca alteração entre estes dois períodos. Sendo assim, a análise foi elaborada sobre a imagem de 1957 (Figura 7). É possível observar que a origem deste assentamento é bastante isolada dos outros centros urbanos da região. Por estar cercada, de um lado, pelos campos de dunas e, do outro lado, pelo Oceano Atlântico, no primeiro registro aerofotogramétrico deste assentamento, a comunidade comporta-se como uma ilha, já que não há ligações diretas com outras localidades. O acesso à esta comunidade se dava pelo mar, com uso de embarcações e também via terrestre, a pé, por caminhos sobre os campos de dunas que cercavam a comunidade ou pelas praias.

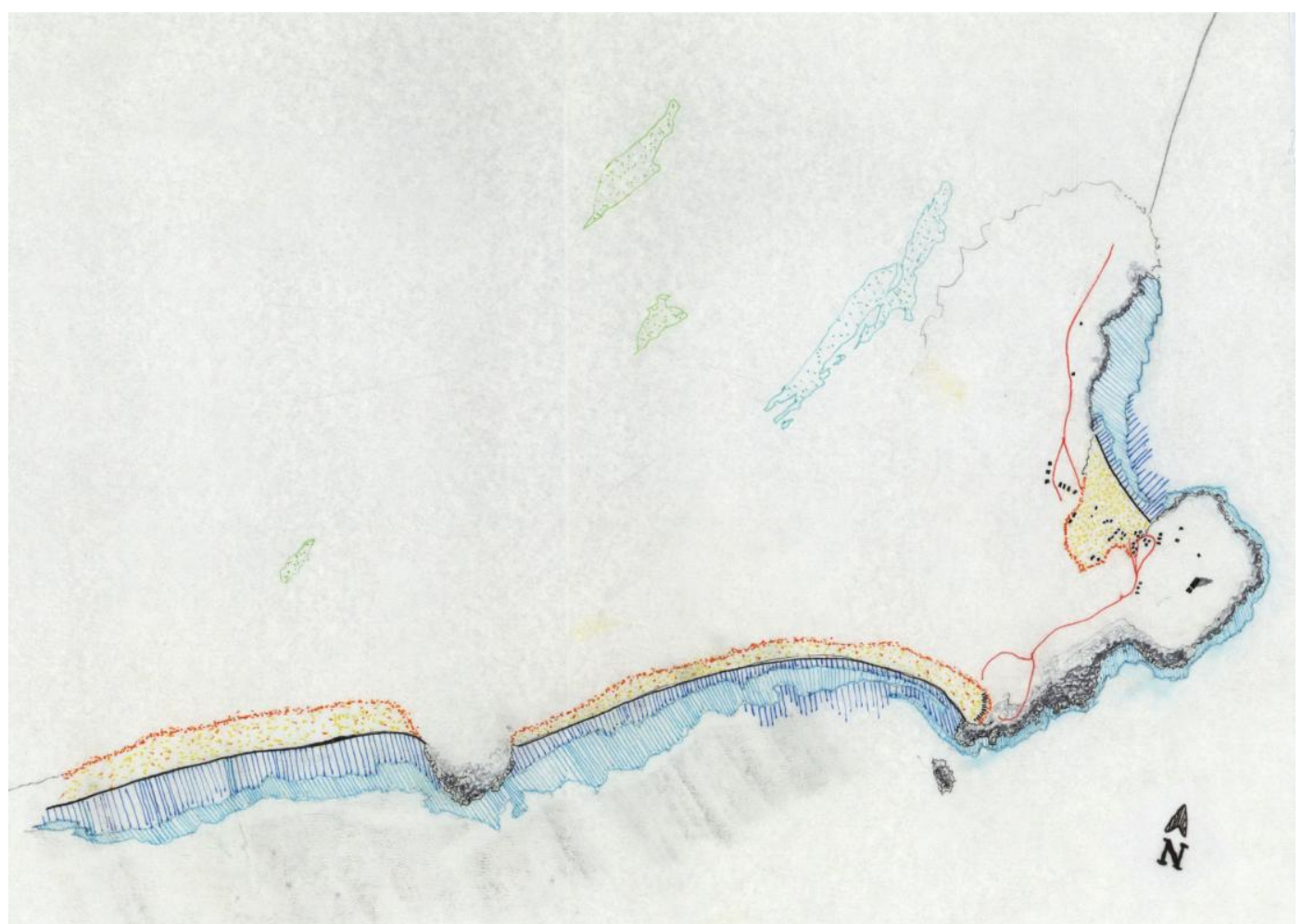

Figura 7 - Farol de Santa Marta no período de 1938 a 1957

Elaboração própria a partir de dados Santa Catarina, 2016 - Desenho, Vinícius S. Rzatki. 
Neste período analisado, evidencia-se apenas uma das três operações urbanas elencadas por SoláMorales (1993): a edificação. Isto se deve à precariedade dos caminhos e à inexistência de uma infraestrutura urbana mais complexa. Acredita-se também que, neste período analisado, não havia um parcelamento da terra estabelecido e as edificações eram dispostas pelo território de acordo com a sua necessidade de abrigo das intempéries. Buscando relacionar aforma original deste assentamento com os tipos de crescimento proposto por Solá-Morales (1993), acredita-se que esta é muito semelhante ao tipo que o autor denomina de Barraca, onde apenas as edificações são observadas dentre as demais operações urbanas apresentadas pelo autor.

As disposições destas edificações ocorrem ao longo dos poucos caminhos existentes (infraestruturas rudimentares), e também se dispersam pelo território que ocupam. As edificações de uso residencial tendem a ocupar a face norte do promontório, por ser mais abrigada dos ventos fortes que vêm do sul. As edificações que existem na face sul não são de uso residencial, mas usadas como abrigo de embarcações e de outros artefatos que os antigos pescadores utilizavam em suas atividades laborais. Os caminhos verificados neste período vão sofrer alterações significativas ao longo das observações sobre as imagens dos períodos posteriores. Alguns destes assumirão características de vias principais, outros continuarão como caminhos de pedestres e, outros ainda, desaparecerão. Além dos caminhos distinguidos nas observações, acredita-se que algumas rotas eram feitas pelas próprias praias, que assumiram, então, este caráter de percurso.

Neste primeiro período de análise observou-se que os principais sistemas ambientais são praias, as dunas e o costão rochoso. As dunas, neste período, estão praticamente descobertas de vegetação, o que leva a crer que havia uma certa mobilidade deste sistema pelo território. Apesar de existirem poucas edificações e com praticamente nenhuma infraestrutura que atendesse a esta comunidade, acredita-se que este assentamento, neste período, deva ser considerado como um sistema urbano rudimentar, devido à precariedade de suas infraestruturas. A presença de dois Sambaquis também é perceptível já na imagem de 1938 e chama a atenção devido à sua relevância histórica.

A partir da análise das imagens de 1977 (Figura 8), nota-se que o território desta comunidade, até então isolada, conecta-se com a rodovia estadual SC 100, via precária na época, mas que, acreditase já ter sido um dos principais acessos ao sul do Brasil. Com isso, a comunidade deixa de ter o antigo caráter de isolamento, observado na análise do período anterior, e passa a ser descoberta por pessoas que buscam o ócio junto às paisagens naturais. Observa-se então um aumento significativo de edificações e acredita-se que parte delas já eram utilizadas, de maneira informal, para abrigar pessoas não nativas desta localidade. 


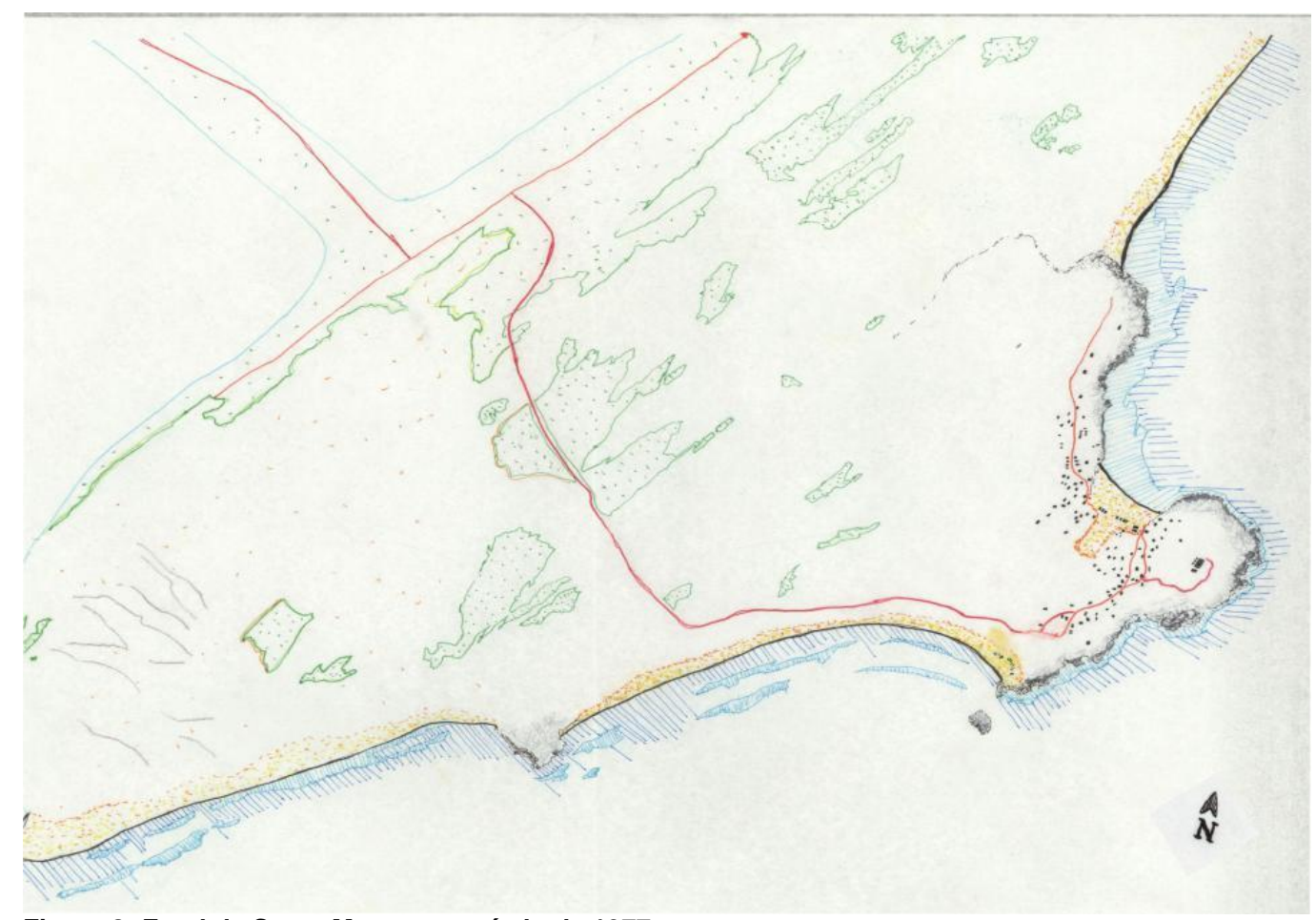

Figura 8- Farol de Santa Marta no período de 1977

Elaboração própria a partir de dados Santa Catarina, 2016 - Desenho, Vinícius S. Rzatki.

Quanto aos caminhos pré-existentes, neste período um pouco mais recente, foi notado que passaram por algumas transformações. O caminho principal manteve-se e assumiu um caráter de via principal, concentrando a maioria das edificações com usos diversos, além do residencial. Acreditase que existiam também pequenos comércios e alguns serviços essenciais para a comunidade àquela época.

A disposição das edificações no sítio, aparentemente, não segue um padrão regular de inserção. Da mesma forma, não é possível identificar com clareza o parcelamento do lote, passando a impressão de que não há uma lógica racional e formal na organização destas parcelas. Acredita-se que isto ocorra em função de que o número edificações foi aumentando à medida em que as famílias que deram origem a este assentamento foram se ampliando, de maneira espontânea, sendo as parcelas definidas pelos próprios integrantes destas famílias, de acordo com suas necessidades espaciais.

Duas alças viárias articulam-se com a via original e servem de acesso a outras edificações, que se encontram um pouco mais afastadas do caminho principal. Começa então a delinear-se uma malha viária, sinuosa, que se acomoda às características do terreno acidentado do promontório.

Ainda neste segundo momento de análise, 1977, observou-se que os principais sistemas ambientais permanecem sem grandes modificações. Começa a se destacar o aumento da vegetação sobre as dunas. Apesar deste aumento da cobertura vegetal, acredita-se que, neste período, ainda havia uma certa mobilidade deste sistema pelo território.

Devido ao aumento do número de edificações e com a provisão de estrutura de acesso e demais infraestruturas, pode-se dizer que, neste período, o sistema urbano se fortalece, agregando um pouco mais de complexidade ao conjunto de sistemas ambientais do Farol de Santa Marta. Logo, neste período, tem-se então os seguintes sistemas ambientais: praias, dunas, costão rochoso e o sistema urbano, que passará por um processo de crescimento bastante significativo nos próximos períodos de análise.

Durante o intervalo entre os anos de 1977 a 2016 verifica-se uma maior intensidade na velocidade da ocupação. A consolidação dos acessos ao Farol de Santa Marta, assim como a divulgação de suas belas paisagens e a qualidade de suas ondulações, fazem com que a localidade seja cada vez mais 
procurada como destino turístico. A pavimentação da rodovia SC-100, favoreceu e intensificou esta procura.

A imagem de 2016 (Figura 9) permite-nos observar agora uma infraestrutura viária conformando uma malha urbana mais estabelecida. Ampliou-se a quantidade de vias existentes no assentamento e, a maioria delas, apresenta um desenho sinuoso que se adapta às condições da topografia local.

Houve investimento por parte do estado nas principais infraestruturas do assentamento, como o calçamento da via principal, identificada desde a imagem de 1938. Esta via, articulada com outra via aberta num período mais recente existente, forma um binário que minimiza os conflitos de mobilidade, já que a malha existente é bastante elementar.

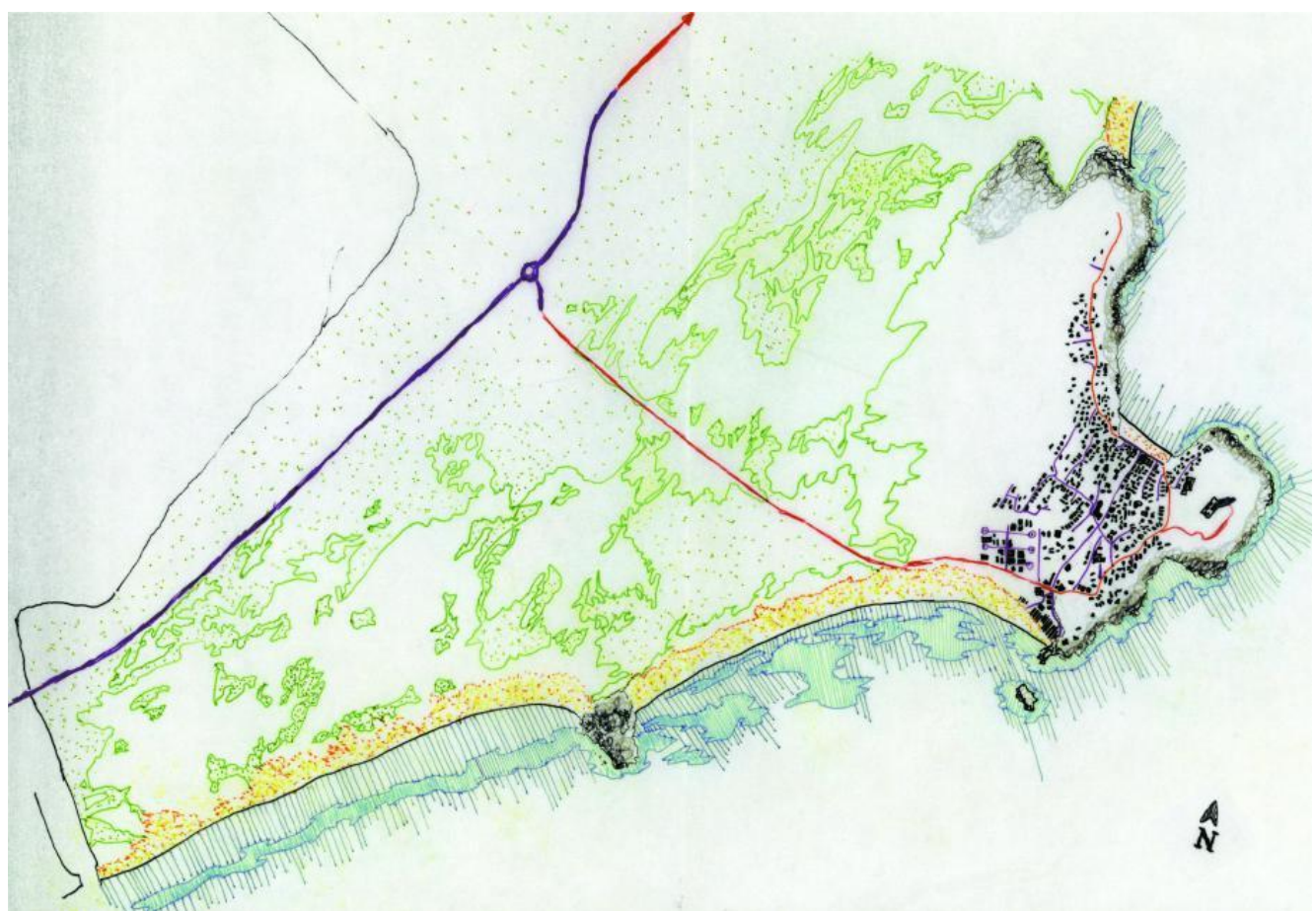

Figura 9 - Farol de Santa Marta no período de 2016

Elaboração própria a partir de dados Google 2016 - Desenho, Vinícius S. Rzatki.

Apesar de não ficar evidenciado nas análises gráficas, mas em observações de campo, verificou-se que, neste período, muitas das parcelas foram isoladas por muros ou cercas. A evolução do parcelamento do Farol de Santa Marta, no intervalo entre os anos de 1978 a 2016, ocorreu através da seguinte sequência de operações urbanas: Edificação - Infraestrutura - Parcelamento, resultando no tecido urbano que hoje se apresenta neste assentamento estudado. Entende-se que este tecido urbano atual é a resultante do tipo de ocupação original, a Barraca de Solá-Morales (1983), associada a outras formas de parcelamento ocorridas ao longo dos processos de crescimento desta localidade.

$\mathrm{Na}$ observação desta imagem mais recente, chama a atenção também o fato que, com o aumento da intensidade de ocupação, houve uma dispersão da mesma sobre o território. A ocupação não se concentra mais apenas ao norte do promontório, que oferecia abrigo da intensidade dos ventos, observa-se que, além do aumento do número de edificações na área já ocupada, muitas delas passam a ocupar a porção centro-sul do promontório onde situa-se a localidade.

Destaca-se nesta imagem da ocupação mais recente, uma malha ortogonal, com um desenho regular, composta de uma via principal que atravessa três outras vias que se encerram em cul de sacs de ambos os lados. Trata-se de um condomínio fechado que contrasta com a irregularidade até então verificada na ocupação do Farol de Santa Marta. A dimensão das projeções das edificações no interior deste condomínio também rompe com as dimensões do que se era construído até então. 
Apesar do expressivo aumento do número de vias (quadro 2), muitas das edificações são acessíveis apenas por caminhos de pedestres uma vez que, grande parte delas, incluindo as mais recentes, não possuem acesso direto às vias existentes. Em muitos casos, de acordo com observação no local, pedestres, motociclistas e ciclistas, compartilham estes caminhos. Também chama a atenção o fato de coexistirem várias edificações dentro de uma mesma parcela, sem acesso direto às vias existentes.

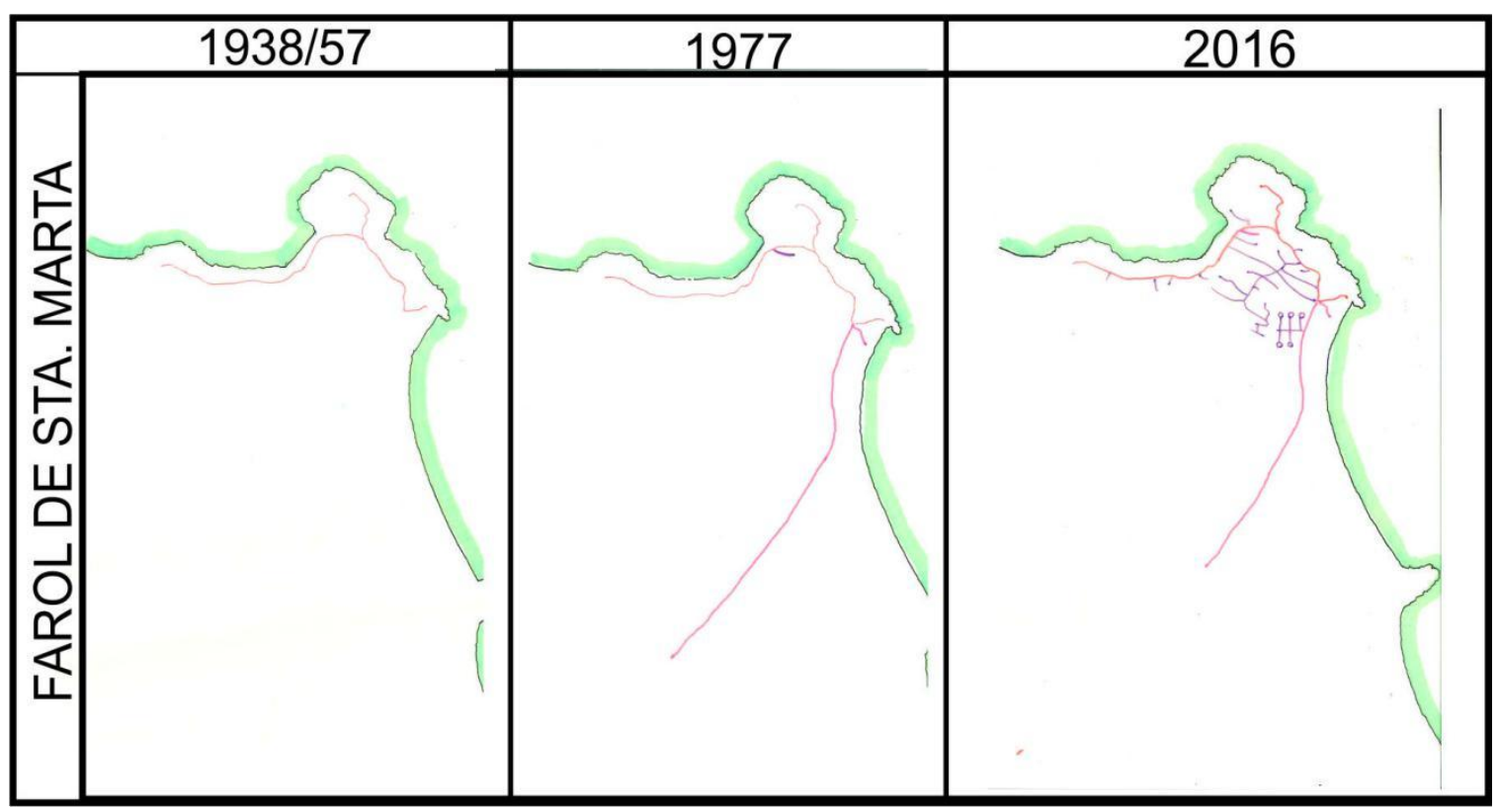

Quadro 2 - Processo de crescimento da malha urbana

Elaboração própria a partir de dados Santa Catarina, 2016. - Desenho Vinícius S. Rzatki.

Chama a atenção também nestas imagens, que o sistema de dunas no entorno do assentamento diminui à medida que a paisagem é antropizada, bem como a praia abrigada do farol, que teve sua faixa de areia subtraída para construção de uma via pavimentada.

\subsection{Itapirubá}

De maneira semelhante ao que foi verificado no Farol de Santa Marta, as fotos aéreas dos períodos de 1938 e 1958 (Figura 10) de Itapirubá apresentam poucas alterações e, portanto, foram analisadas em conjunto. Da mesma forma, nestes períodos, a comunidade de Itapirubá encontrava-se isolada de outros núcleos urbanos, já que também se situava num promontório entre o campo de Dunas e o Oceano Atlântico. Acredita-se que suas conexões com o centro de Laguna e outras regiões ocorriam pelo mar, com o uso de embarcações, e via terrestre, por caminhos identificados sobre as dunas que cercavam Itapirubá ou ainda pelas praias. 


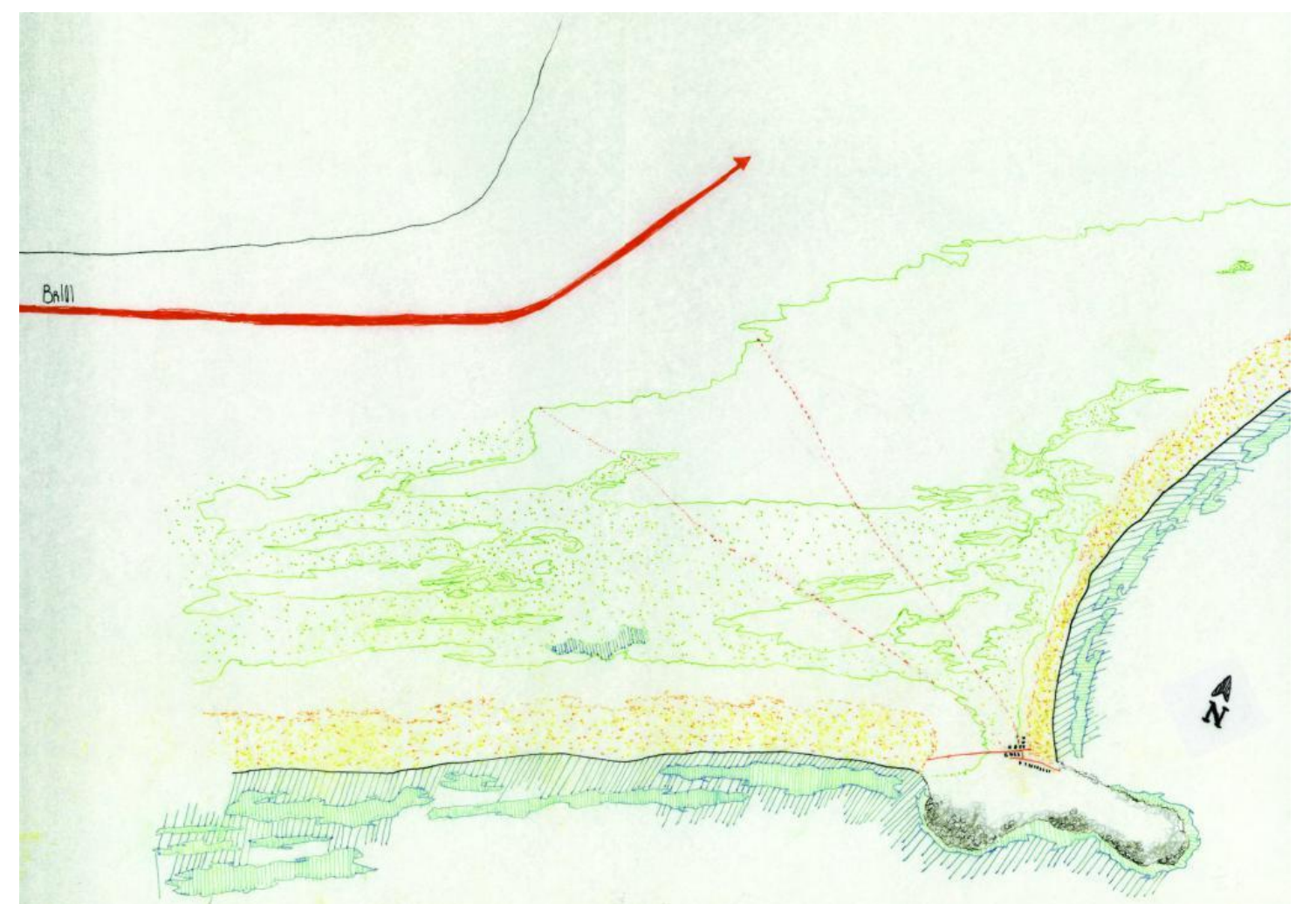

Figura 10 - Itapirubá no período entre 1938 a 1957

Elaboração própria a partir de dados Santa Catarina, 2016. - Desenho Vinícius S. Rzatki.

Itapirubá formou-se a partir de uma comunidade pesqueira, onde as edificações foram dispostas junto à base norte do promontório, protegida dos ventos predominantes sul e nordeste. Não foi observado a existência de parcelamento e nem de infraestruturas nas imagens deste território neste período inicial.

As edificações existentes na origem do assentamento de Itapirubá configuram o que viria a ser o primeiro caminho existente, pois encontram-se alinhadas entre elas e não foi verificado a presença de edificações dispersas neste período - fato que foi observado no Farol de Santa Marta - e, também de forma diferente, não foi notada a presença de edificações com função de rancho de pesca no lado sul do promontório. Se estas existiram neste período, estariam dispostos no lado norte do promontório, junto com as demais edificações.

Observou-se também que os caminhos originais, no caso de Itapirubá configurado pela disposição das edificações, não sofrerão alterações, isto é, vão permanecer nos períodos posteriores que serão analisados. Estes caminhos irão transformar-se em vias existentes até os dias atuais. Chama a atenção também, um caminho que fazia a ligação, sobre as dunas, em direção às terras cultivadas, localizadas à oeste, após o campo de dunas. Este caminho virá estruturar, no futuro, o acesso ao assentamento, até então inexistente.

Os sistemas ambientais verificados neste primeiro período de análise são praia, dunas, costão rochoso e laguna costeira, este último, de dimensões bastante reduzidas. Assim como ocorreu no outro assentamento estudado, o sistema urbano, neste período se caracteriza de forma bastante primitiva, pois não havia um mínimo de infraestrutura para ser entendido de outra forma. Em Itapirubá não foi observada a presença dos sambaquis, como no caso anterior.

No segundo período analisado, 1977, (Figura 11), nota-se que o assentamento de Itapirubá deixa de ser uma comunidade isolada devido a duas conexões com a BR-101, na década de 1970. Estas conexões são estabelecidas a partir de dois caminhos que ligavam a comunidade às terras cultivadas, elas são percebidas de maneira bastante evidente nas análises das imagens deste período e, da mesma maneira, fica claro o adensamento ocorrido junto à primeira ocupação. 
Observa-se também a configuração de uma malha viária e o parcelamento do solo, ambos originados a partir dos dois caminhos primitivos. Remetendo ao estudo de Solá-Morales (1993), supõe-se que a sequência de operações urbanas, encadeadas na constituição do tecido urbano originado a partir do núcleo original do assentamento, teria sido Edificação - Infraestrutura e Parcelamento.

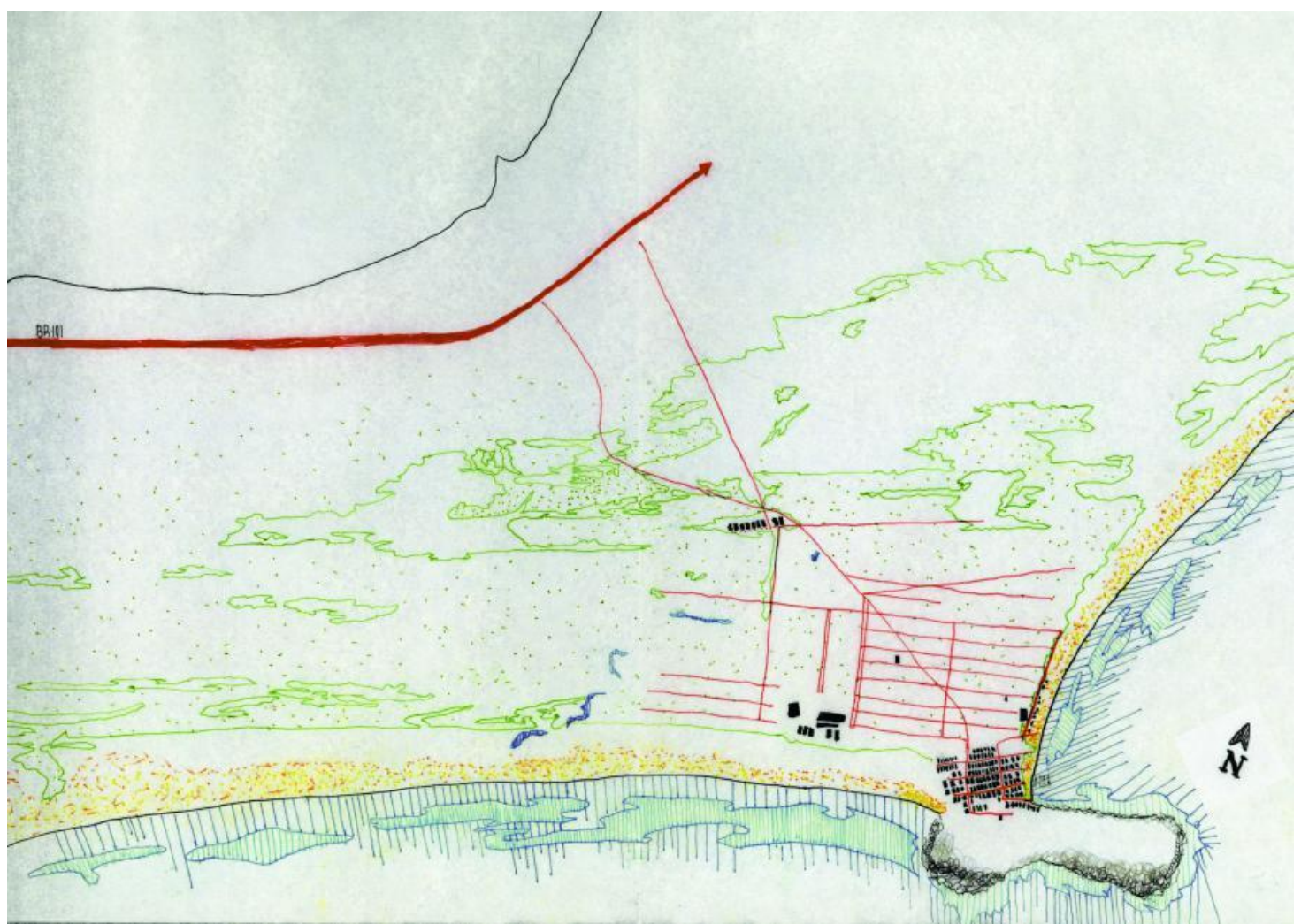

Figura 11 - Itapirubá no período de 1977

Elaboração própria a partir de dados Santa Catarina, 2016 - Desenho, Vinícius S. Rzatki.

Esta primeira malha, segue os alinhamentos dos primeiros caminhos, de forma bastante racional e, acredita-se, que tenha surgido não só pela necessidade de moradia dos descendentes dos pescadores nativos, mas também pela busca de locais de lazer junto ao sol e ao mar. À esta primeira malha, percebe-se que foi inserida uma outra malha, dotada de infraestrutura, que se distingue do desenho original, tanto pela direção do sentido das suas vias, quanto pelo tamanho de suas quadras. Esta nova urbanização segue o alinhamento da orla da praia de Itapirubá Sul e estende-se em direção ao sul, cujos limites coincidem com a dissipação da infraestrutura.

Ao Sul deste novo assentamento nota-se uma diferenciação no desenho da malha urbana. Este trecho apresenta sinais de planejamento para uma área em crescimento contínuo, em direção ao Sul, e que permanece em vias de desenvolvimento até o período de 2016. O registro da aerofoto de 1977 demonstra o processo de implantação da primeira fase deste novo loteamento e observa-se que, entre o final da primeira etapa e o início da segunda etapa de sua implementação há um grande um grande empreendimento hoteleiro. Isto reforça o investimento voltado ao turismo por parte dos empreendedores do lugar.

Neste período analisado observa-se uma alteração nos sistemas ambientais verificados no momento anterior. O sistema praia sofre uma diminuição na largura de sua faixa de areia, fato observado em Itapirubá Norte. O sistema dunar, que originalmente conectava as praias de Itapirubá Sul e Norte foi totalmente ocupado pela primeira malha registrada nesta localidade. O sistema laguna costeira, de dimensões reduzidas, observado no período anterior, neste momento da análise está passando por transformações em sua forma e dimensão, dividindo-se em uma série de pequenas lagoas sobre as 
dunas existentes. Supõe-se que esta transformação ocorra em função da construção deste empreendimento urbano em fase de implantação. O sistema urbano, antes embrionário, encontra-se agora bastante evidenciado, em função da série de investimentos em infraestruturas que vem ocorrendo no território de Itapirubá.

A ocupação que já se mostrava forte no final da década de 1970, fica ainda mais intensa ao se observar a imagem de 2016 (Figura 12), onde se percebe a continuidade da implantação do loteamento Itapirubá Sul, com a abertura de novas vias. Uma das duas vias de acesso, que se originaram dos caminhos às terras cultivadas, na década de 1930, foi suprimida e deixou de seccionar a segunda malha urbana existente em Itapirubá.

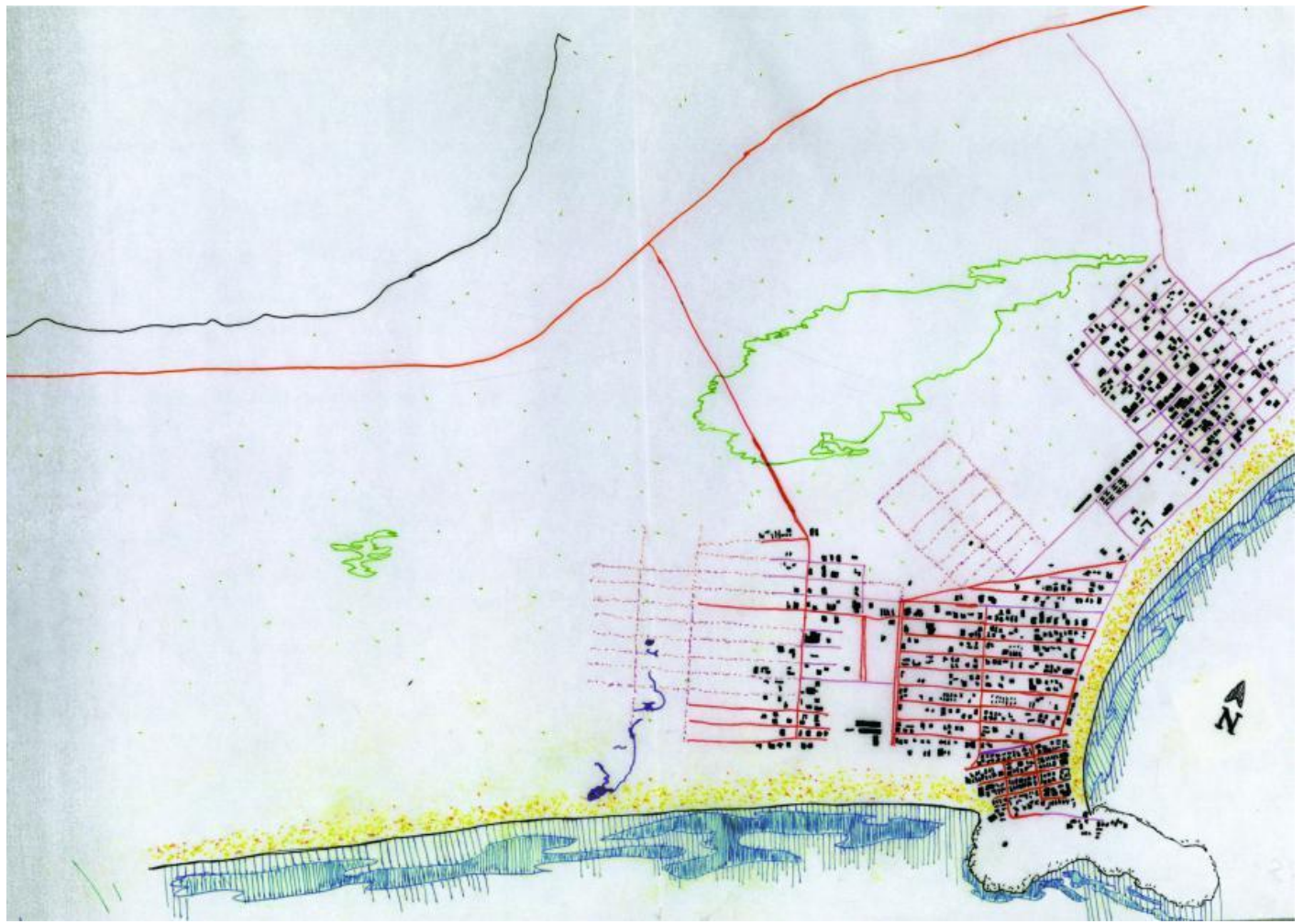

Figura 12 - Itapirubá no período de 2016

Elaboração própria a partir de dados Santa Catarina, 2016 - Desenho, Vinícius S. Rzatki.

A praia de Itapirubá Norte, por sua vez, também recebeu um investimento de infraestrutura urbana voltada para o turismo. $O$ desenho desta terceira malha, verificada nesta pesquisa, distingue-se das demais pois a implantação de suas quadras ocorre paralela à praia onde está inserida. Este terceiro loteamento, situado no território do município de Imbituba tem um acesso independente, mais recente, vindo também da BR-101.

Os novos loteamentos seguem uma lógica de crescimento e encadeamento de operações urbanas onde o investimento inicial é a Infraestrutura, seguido ou simultâneo, do Parcelamento e, posteriormente, Edificação. Estes processos de crescimento mais atuais diferenciam-se do que foi verificado nas décadas de 1930 e 1950, onde a ocupação se iniciava com a edificação.

$\mathrm{Na}$ imagem mais recente, de 2016, os sistemas ambientais mostram-se alterados em relação aos observados na década de 1930. O sistema urbano teve um aumento significativo; a cobertura vegetal do sistema de dunas ampliou-se consideravelmente, praticamente deixando de existir dunas sem a cobertura vegetal, O sistema laguna vai cedendo lugar à ampliação do novo loteamento da praia de Itapirubá em direção ao Sul e o sistema costão rochoso permaneceu praticamente inalterado. (Quadro 3) 


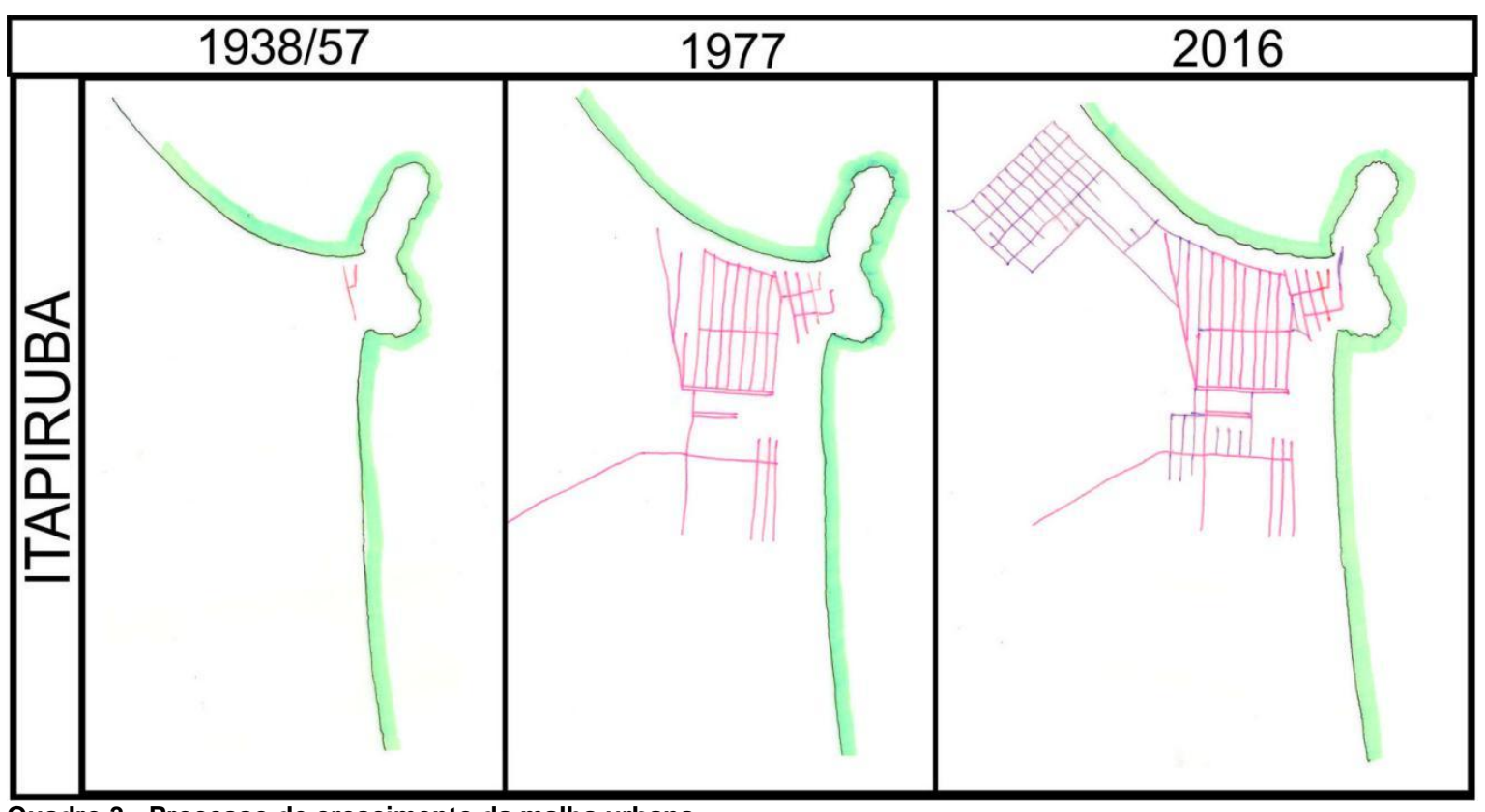

Quadro 3 - Processo de crescimento da malha urbana

Elaboração própria a partir de dados Santa Catarina, 2016. Desenho, Vinícius S. Rzatki.

\section{CONSIDERAÇÕES FINAIS}

Esta pesquisa encontra-se em desenvolvimento e espera-se como resultado compreender os processos de crescimento urbano dos assentamentos urbano turísticos do município de Laguna. Pretende-se também identificar, sumariamente, os sistemas ambientais e os principais impactos causados ao meio natural em função da evolução da ocupação urbana. Espera-se também identificar, neste trecho da costa sul catarinense, os diferentes tipos de ocupação urbana voltadas ao turismo e a relação que estes mantém junto a este meio natural onde se inserem, considerando os valores destes sítios litorâneos ambientalmente sensíveis.

Durante o processo deste estudo, partiu-se do pressuposto de que, estes dois assentamentos apresentavam muitas semelhanças entre si, principalmente durante a origem de suas ocupações, nos períodos de 1938/1957, porém, com as análises gráficas elaboradas sobre as imagens em diferentes períodos, de 1977 e 2016, verificou-se que estes sítios, mesmo sendo semelhantes em relação ao seu isolamento geográfico, sua população de origem pesqueira e seu sítio físico, apresentam distinções observadas já no segundo momento da análise (1977).

A principal distinção observada foi em relação a evolução da malha urbana, que no Farol de Santa Marta permanece de maneira irregular até os dias atuais e, em Itapirubá, a malha original permanece irregular apenas junto ao promontório e, de acordo com a expansão do assentamento, a malha se apresenta de maneira bastante regular.

Outras diferenças observadas durante a evolução desses assentamentos foram quanto a forma e a localização das parcelas em relação ao sistema viário. Enquanto que no Farol de Santa Marta, as parcelas são irregulares devido aos desmembramentos terem ocorridos, muitas vezes, de forma hereditária; em Itapirubá, estes desmembramentos ocorreram em função de investimentos privados visando atender a uma especulação imobiliária voltada ao turismo, que já se anunciava de forma promissora desde a década de 1970. Com o passar dos anos, estas diferenças acentuaram-se, tornando estes assentamentos completamente distintos entre si em função de seus distintos processos de crescimento.

A relação das parcelas com o sistema viário também se diferencia quando comparadas estas duas localidades. Isto se justifica devido às diferenças de processos de crescimento que gerou as diferentes formas de desmembramento comentadas anteriormente. A irregularidade do parcelamento do Farol de Santa Marta fez com que algumas parcelas se situem junto à via principal, enquanto 
outras são conectadas a esta via por servidões ou ainda por caminhos informais dentro dos lotes junto às vias. Em Itapirubá, em função dos desmembramentos terem ocorrido de forma ordenada e regular, praticamente todas as parcelas mantêm uma relação direta com o espaço público.

Verificou-se também que, os sistemas ambientais identificados nos diferentes períodos estudados vão se alterando à medida em que aumenta a ocupação humana em ambos os assentamentos. Chamou a atenção, particularmente, a alteração de dois sistemas: o sistema dunar, que nas primeiras imagens praticamente não apresentava vegetação que as fixassem, e o sistema urbano, que avança consideravelmente sobre os demais sistemas, chegando ao ponto da quase extinção de um deles, o laguna costeira, que em Itapirubá, "vai se dissolvendo" em função do avanço da urbanização.

Por fim, verificou-se que este método de análise sobre imagens aéreas e de satélite mostrou-se adequado nesta análise por possibilitar a visualização do crescimento enquanto processo temporal. Este trabalho deve ser continuado e aprofundado, relacionando as observações constatadas com documentações oficiais para um maior entendimento da evolução destes processos de crescimento urbano-turísticos verificados no sul do Estado de Santa Catarina.

\section{BIBLIOGRAFIA}

\section{Obra completa:}

BRASIL (2004). PROJETO ORLA: Fundamentos para gestão integrada. Brasília: Mma/sqa, 2006. (2004). PROJETO ORLA: Subsídios para um projeto de gestão. Brasília: Mma/sqa.

CITTADIN, A. P. (2010). Laguna, Paisagem e Preservação: O Patrimônio Cultural e Natural do Município. Dissertação de Mestrado - PÓSARQ/UFSC. Florianópolis.

LUCENA, L. M. F. Laguna: de ontem e hoje espaços públicos e vida urbana. 1998. Dissertação Mestrado em Desenvolvimento Regional e Urbano. Departamento de Geociências. UFSC.

MORAES, A. C. (2007). Contribuições para a gestão da zona costeira do Brasil: Elementos para uma geografia do litoral brasileiro. 2. ed. São Paulo: Annablume Editora.

REIS, A. F. (2012). Ilha de Santa Catarina: permanências e transformações. Florianópolis. EdUFSC. SOLÁ-MORALES, M. (1997). Las formas del crecimiento urbano. Barcelona: Edicions Upc.

SPIRN, A. W. (1993) O jardim de granito: a natureza no desenho da cidade. São Paulo. EdUSP.

\section{Capítulo de livro:}

SILVA, N. S. (2005). A escala do presente: o litoral catarinense. En N. SARAIVA DA SILVA, Arquitetura da maior e menor escala: Vivências, projetos, e reflexões sobre os lugares marinheiros catarinenses. (177-395). São Paulo: Cetd.

\section{Apresentações, congressos, conferências e seminários:}

BUENO, A. P. (2016). Benindorm e Balneário Camboriú. Comparações entre ícones do turismo de sol e praia urbano. VIII Seminário Internacional de Investigação em Urbanismo, Balneário Camboriú, junho de 2016 (meio digital).

GIOVANNI, E.N. (2016). Território Costeiro em Transformação: Investigação sobre os processos de crescimento das estruturas urbano-turísticas no município de Laguna - Brasil. VIII Seminário Internacional de Investigação em Urbanismo, Balneário Camboriú, junho de 2016 (meio digital).

\section{Revistas e periódicos:}

REIS, Almir Francisco. (2000). Forma y apropriación del espacio publico en núcleos urbanos resultantes del proceso de desarrollo turístico en la isla de Santa Catarina-Brasil. Scripta Nova (Barcelona), 69, 1-11.

SCHERER, M.E.G. AND ASMUS, M.L. (2016). Ecosystem-Based Knowledge and Management as a tool for Integrated Coastal and Ocean Management: A Brazilian Initiative. In: Vila-Concejo, A.; Bruce, E.; Kennedy, D.M., and McCarroll, R.J. (eds.), Proceedings of the 14th International Coastal Symposium (Sydney, Australia). Journal of Coastal Research, Special Issue, No. 75, Volume 1, pp. 690-694. Coconut Creek (Florida), ISSN 0749-0208.

; FERREIRA, C.; MUDAT, J.; CATANEU, S. (2006). Urbanização e gestão do litoral Centro Sul do Estado de Santa Catarina. Desenvolvimento e Meio Ambiente, n. 13, p. 31-50. Jan-jun, Rio de Janeiro, 2006. 


\section{Fonte eletrônica:}

http://www.spg.sc.gov.br/. SANTA CATARINA. Secretaria de Estado de Planejamento. GECAR Geografia e cartografia. (Consulta: 15/01/2017).

https://maps.google.com.br/ (Consulta: 15/01/2017).

http://biblioteca.ibge.gov.br/visualizacao/livros/liv55263.pdf (Consulta 25/04/2017). BRASIL. Maria

Luísa Gomes Castello Branco. IBGE. Atlas geográfico das zonas costeiras. Rio de Janeiro:

lbge, 2011.

http://www.censo2010.ibge.gov.br/sinopse/index.php?uf=42\&dados=0. (Consulta 25/04/2017)

BRASIL.IBGE. Sinopse do censo demográfico 2010.

http://www.icmbio.gov.br/apabaleiafranca. (Consulta 25/04/2017). BRASIL. ICMBio. APA da baleia franca. 